\title{
Drivers of biodiversity conservation in sacred groves: A comparative study of three sacred groves in southwest Nigeria.
}

\author{
Samuel Adeyanju' ${ }^{1}$, Janette Bulkan'1, Jonathan Onyekwelu², Guillaume Peterson St-Laurent, Robert \\ Kozak $^{1}$ Terry Sunderland ${ }^{1,3}$ and Bernd Stimm ${ }^{4}$ \\ 1 Faculty of Forestry, University of British Columbia, Vancouver, Canada. \\ 2 Department of Forestry and Wood Technology, Federal University of Technology, Akure, \\ Nigeria. \\ 3 Centre for International Forestry Research, Bogor, Indonesia. \\ 4 Chair of Silviculture, Technical University of Munich, Freising, Germany. \\ * Correspondence: author: Samuel.adeyanju@ubc.ca;ORCID: https://orcid.org/0000-0002- \\ 7506-1591
}

\begin{abstract}
Globally, sacred groves represent a traditional form of community-based conservation system, recognized for their capacity to preserve areas that are of cultural and religious importance to local people. In most cases, the entire community takes on a watchdog role to guard against encroachment and unauthorized access either by its members or outsiders who might desecrate such sites. Our paper investigates the effects of different governance arrangements on three sacred groves in southwest Nigeria-Osun Osogbo Sacred Grove (UNESCO World Heritage Site); Idanre Hills (Nigerian National Monument) and Igbo-Olodumare (local cultural site)-on their socio-economic and religio-cultural benefits and contribution to biodiversity conservation. Using a mixed-methods design of a semi-structured questionnaire $(n=167)$, key informant interviews $(n=2)$, and focus groups $(n=7)$, we collected data from local community members, traditional priests, sacred grove devotees and tourism officials. We found that customary institutions have guided reverence for sacralized spaces and wise utilization of their unique resources. The growing recognition of sacred groves has paved the way for socioeconomic rewards for individuals and government as cultural tourism increases. We found that the involvement of formal institutions alongside customary institutions in sacred grove management reinforces compliance with conservation laws within the sacred groves, especially where traditional norms are weak or may be disregarded. We discuss the implications of these observations and offer suggestions to improve community engagement, uphold traditional ecological knowledge, and develop ecotourism within the groves. We conclude that the co-existence of community-based conservation through a system of established traditional norms and prohibitions as well as formal government legislation and management, offers assurance for the longterm preservation of sacred groves and their biodiversity.
\end{abstract}

Keywords: Sacred groves; biodiversity conservation; Community-based conservation; Indigenous People; Nigeria

\section{INTRODUCTION}

"Sacred Natural Sites" is a broad term used to refer to land or water bodies that have special spiritual significance to peoples and communities (Verschuuren et al., 2010). These sacred natural sites can include individual 
trees, forests, rivers, waterfalls, meadows, wildlife, caves, lakes and hills (Bhagwat and Rutte, 2006; Liljeblad and Verschuuren, 2019; Ormsby, 2012a; Samakov and Berkes, 2017).

Sacred groves are increasingly recognized as a traditional form of community-based conservation, even as they preserve areas that hold strong cultural and religious importance to local people (Bulkan, 2017; Ormsby and Bhagwat, 2010). The protection and preservation of these sacred sites are closely linked to enduring religious beliefs, community developed rules, and complex socio-cultural and spiritual associations with deities and ancestral spirits (Aniah and Yelfaanibe, 2016; Mgumia and Oba, 2003). Hence, their recognition as spiritual/sacred commons (Rutte, 2011; Samakov and Berkes, 2017). While sacred groves were not created primarily for biodiversity conservation (Onyekwelu, 2021; Sheridan, 2009), they are often the only remaining patches of natural or semi-natural habitats in several landscapes. Other sacred groves have been heavily modified, degraded and sometimes deforested, making them ecologically unsustainable (Dudley et al., 2010). Nonetheless, the aggregate contributions of sacred groves to biodiversity conservation, ecosystem resilience and protection against intense land-use pressures are widely recognized (Bhagwat and Rutte, 2006; Rutte, 2011). The rich biodiversity found in sacred groves sometimes exceeds those of nearby protected areas and State-managed forest reserves, underlining their relational importance (Onyekwelu and Olusola, 2014).

Sacred groves are found in many countries globally, especially common in parts of Asia and Africa (Verschuuren et al., 2010). In Asia, sacred groves are found in many parts of India, Nepal, and China (Bhagwat and Rutte, 2006; Brandt et al., 2013). Studies indicate that India has some of the highest numbers and concentration of sacred natural sites in the world, with estimates of 100,000-150,000 (Malhotra et al., 2001). Nonetheless, most of these sacred groves are less than one hectare in size; cumulatively, they cover only 0.01 per cent of India's geographic area (Ormsby, 2012b). In Latin America, sacred sites are located on the territories of Indigenous Peoples (Gabay et al., 2012).

Similarly, sacred groves are prevalent in many countries in tropical Africa, including Tanzania (Mgumia and Oba, 2003), Ghana (Aniah and Yelfaanibe, 2016; Ormsby, 2012a, 2012b), Nigeria (Daniel et al., 2016; Onyekwelu and Olusola, 2014; Oyelowo et al., 2014) and Benin (Ceperley et al., 2010). Sacred groves are traditionally associated with deity worship, initiation rituals and sacrifices (Onyekwelu, 2021; Sheridan, 2009). Ghana has some of the highest concentration in Africa with estimates of over 1,900 sacred groves of varying sizes, ranging from less than one hectare to several thousand hectares spread across the country (Ormsby, 2012a).

In southwest Nigeria, sacred groves were historically associated with the Yoruba people, for whom they are a symbol of identity (National Commission for Museums and Monuments (NCMM), 2005). There are no available estimates on the number of groves in Nigeria. Previous studies carried out in Nigeria have focused on Osun Osogbo sacred grove, a UNESCO World Heritage Site in southwest Nigeria, while little attention has been paid to lesser-known sacred sites in the country (Babalola, 2011; Osegale et al., 2014; Oyeleke et al., 2017; Probst, 2013).

In this study, we addressed these knowledge gaps by comparing three sacred groves located in two states in southwest Nigeria: a UNESCO World Heritage Site (Osun Osogbo), a Nigerian National Monument site (Idanre Hills) and a local cultural site (Igbo-Olodumare). Our central research 
questions were: to what extent do perceived socio-economic and religiocultural relationships contribute to biodiversity conservation in sacred groves in southwest Nigeria? How does the scale of governance (formal and informal) influence these relationships and biodiversity conservation in the three sacred groves?

\section{SACRED GROVES AS DRIVERS OF BIODIVERSITY CONSERVATION AND CO-BENEFITS}

By preserving sacred sites, local people derive multiple benefits, in addition to practicing their faiths and upholding their traditional customs (Daniel et al., 2016; Rutte, 2011). Indigenous Peoples' territories overlap with some of the world's remaining significant concentrations of biodiversity (Sobrevila, 2008), and hold about 80 per cent of the planet's biodiversity (Garnett et al., 2018). Although the role of sacred sites in long-term conservation strategies may be limited by their small sizes, they are sites for: biocultural conservation (Samakov and Berkes, 2017); forest bird conservation in southwest China's Himalayan Mountains (Brandt et al., 2013); and for rare, threatened and endangered (RTE) species in many parts of India (Khan et al., 2008).

Similarly in Africa: sacred groves in Tanzania have greater woody species richness and taxonomic diversity than the State-managed forest reserves, although they occupy a relatively small area (Mgumia and Oba, 2003). provide a sanctuary for RTE species in the Bongo District of Ghana (Aniah and Yelfaanibe, 2016); and in the Central Benin Republic, the diversity of tree species in riparian forests is higher in areas adjacent to sacred forests than in areas adjacent to village uses (Ceperley et al., 2010). In Nigeria one study showed that Osun Osogbo had the highest species richness and harboured a higher count of endangered species compared to both degraded and primary forests in southwest Nigeria (Onyekwelu and Olusola, 2014).

Sacred groves provide tangible and intangible benefits to local communities which explain why they are protected (Rutte, 2011). First, sacred groves are an essential part of the cultural and traditional beliefs and activities of local communities (Adesiji and Babalola, 2012), providing a sense of place-based connections built over generations (Liljeblad and Verschuuren, 2019). In Nigeria, sacred groves are the sites for rituals, initiations, festivals and ceremonies including selecting and installing kings (Daniel et al., 2016). They accommodate secrecy and privacy which characterize the worship of deities in many traditional communities (Probst, 2013). In some places, they serve as burial sites for children and 'wicked people' (i.e., those who died mysterious deaths) (Bhagwat and Rutte, 2006). Some Nigerian sacred forests with shrines receive many visitors who seek supernatural solutions to their predicaments, such as strange sicknesses, poverty, joblessness, and fertility issues (Yusuf, 2016).

Second, sacred groves may provide economic benefits for governments and contribute to food security for households (Oyelowo et al., 2014; Udeagha et al., 2013). Developing sacred sites into tourist destinations as in the case of Osun Osogbo, attracts more visitors and generate income (Ormsby, 2012b; Osegale et al., 2014; Probst, 2013, 2016).

\section{METHODOLOGY}

3.1. Study sites 
The selection of three sacred groves was based on three criteria: (1) unique features of each grove (ecology and spectrum of governance), (2) willingness of management to grant access for research and (3) availability of previous studies on the biodiversity conservation status of each (Onyekwelu and Olusola, 2014, see Figure 1).
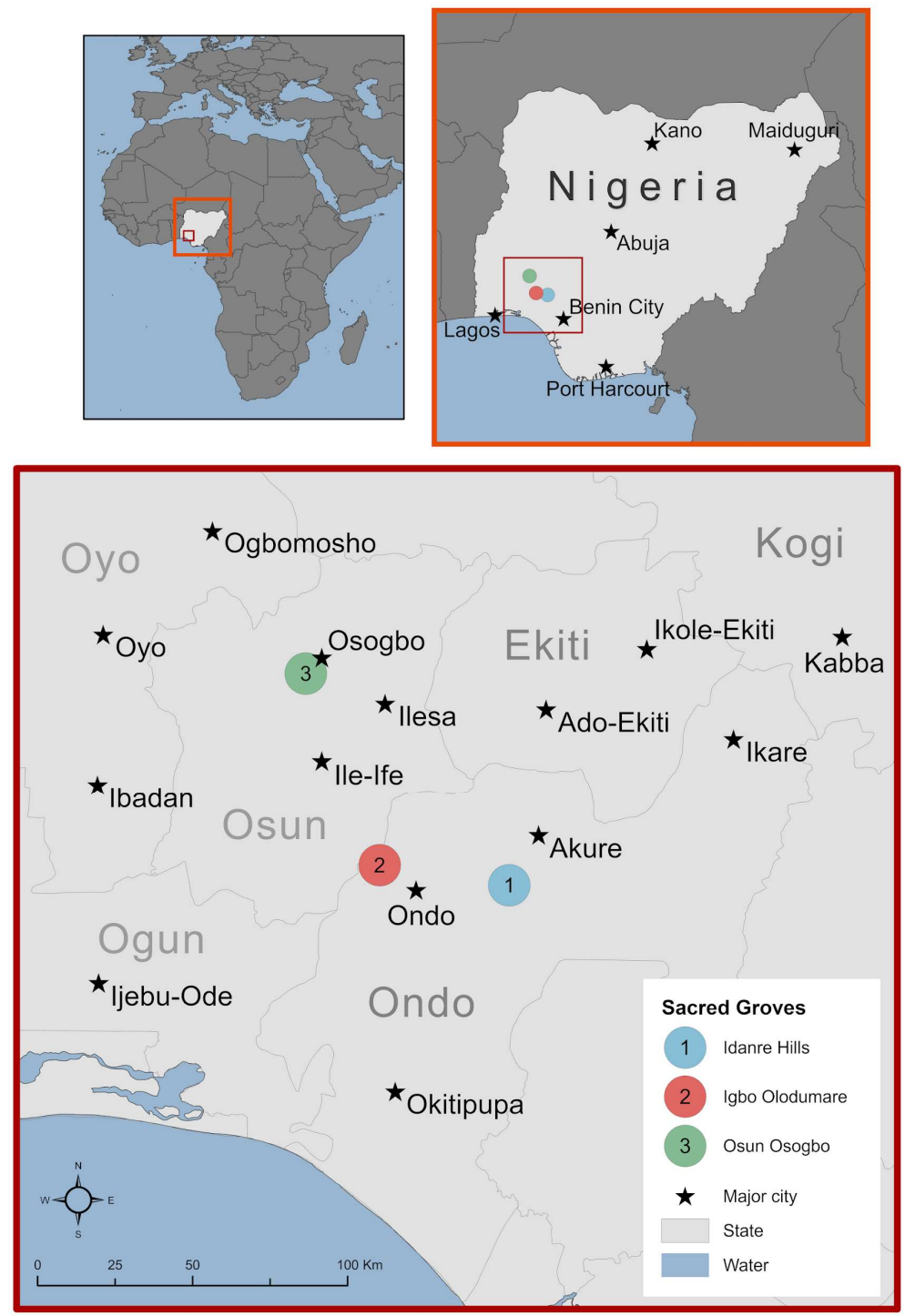

Figure 1. Map of Nigeria showing the study sites.

Osun Osogbo Sacred Grove (hereafter "OOSG") is located along the banks of the Osun River in Osogbo town, Osun State, Nigeria. Founded some 400 years ago, it is the largest sacred grove remaining in Yorubaland (NCMM, 2005). The grove has a forest area of 75 hectares, bounded by a 47 hectares buffer zone (Onyekwelu and Olusola, 2014). In 2005, OOSG was declared a UNESCO World Heritage Site (Probst, 2009). Under the National Commission for Museums and Monuments (NCMM) - the Federal Government Agency that is responsible for protecting cultural heritage in Nigeria and in the case of OOSG employs armed guards to patrol the grove around the clock (Ogundiran, 2014). OOSG harbours over 400 species of plants, and provides habitat for wildlife, including the endangered whitethroated monkey (Cercopithecus erytrogaster), vulnerable putty-nosed monkey 
(C. nictitans) and the threatened red capped mangabey (Cercocebus sp.) (NCMM, 2014; Osegale et al., 2014; Yusuf, 2016). Federal Decree 77 of 1979 conferred legal protected status on OOSG and committed to the preservation of the history, traditional cultures and resources existing within the grove (NCMM, 2005). The decree prohibits tree cutting, hunting, fishing, burning, encroachment for farming or building of houses, and dumping of refuse (Probst, 2013). The forest sanctuary contains 40 shrines, two ancient palaces and many sculptures and artworks in honour of Osun and other deities (Osegale et al., 2014). Osun, the river goddess, is worshipped by many for her powers and supernatural interventions in various predicaments facing the people. OOSG hosts an important annual two week-long festival to honour Osun, during which the current traditional ruler is rededicated to Osun, and the ties between the people of Osogbo and the deities are renewed. The grand finale of the festival is held in the sacred grove (NCMM, 2005). While most parts of the grove are accessible to visitors/tourists, some sections are restricted to only Osun priestesses, Osun adherents and the Ogboni Cult--an elitist society of men of great political and economic influence and affluence (Osegale et al., 2014).

Idanre Hills (locally called Oke-Idanre) is an ancient natural landscape inhabited for almost 1,000 years by the entire people of Idanre (NCMM, 2007). Located in Idanre town in Ondo State, Nigeria, the grove is now reduced to isolated hills with steep sides and rounded tops at about 914.4 metres above sea level. Idanre Hills was declared a National Monument in 2014 (Akinde, 2018) and was nominated as a UNESCO World Heritage Site in 2007 by the Nigerian government through the NCMM. The grove remains on the tentative list of UNESCO World Heritage Sites. The nominated property (Oke-Idanre Cultural Landscape) for UNESCO designation covers an area of 637.7 hectares, with a buffer zone estimated at 2,052 hectares (Akinde, 2018). Only a small section of the entire hill is considered sacred. The grove staff are employed by the Ondo State government under the Ministry of Culture and Tourism, with the involvement of local leaders (king and chiefs), cultural groups and the NCMM (Adigun et al., 2016; Oladeji and Akinrinola, 2010). The forested areas in the grove harbour diverse tree and wildlife species, including 174 insect-, 4 fish-, and 13 mammal species, including monkeys (Cercopithecus sp.), bats (Rousettus Aegyptiacus) and hyrax (Dendrohyrax dorsalis) (Bai et al., 2018; NCMM, 2007). The people of Idanre formerly lived and farmed on the hills before moving downhill in 1923. On the hill top, certain features remain including the ancient palace of Owa (the king), relics of the first court constructed in 1906, the first colonial building built in 1896, Wasp cave, Bat's cave, burial mounds and grounds for Idanre kings (NCMM, 2007; Oladeji and Akinrinola, 2010). Farming still takes place in some parts but not in the sacred sections (NCMM, 2007). As in most Nigerian sacred groves, some sections of Idanre Hills are restricted to only traditional chiefs and priests for the worship of Olofin and Orosun deities, especially some burial sites and old houses used for indoor ritual sessions and prayers. Several traditional festivals are held at specific times during the year, including Orosun, Ije, Usé (bat) and Ogun festivals (Adebayo, 2017; NCMM, 2007). Idanre is the only site in Yorubaland where the Usé (bat) festival has been celebrated biannually for many years (Akinde, 2018).

The third sacred grove assessed was Igbo-Olodumare (translated "The Forest of the Almighty"), a lush rainforest on rocky hills in Oke-Igbo, Ondo State, that covers an area of 7 hectares. The State government through the Ministry of Culture and Tourism is responsible for its protection and 
management and employs a community member in charge of the grove as a curator. The forest became more widely known after 1949 through the writings of D.O. Fagunwa (a Nigerian Yoruba author who pioneered the Yoruba-language novel) which described a forest of "witches, wizards, giant snails, crabs and other mysterious things" (Kolawole, n.d.). Although no sacrifices are made within the forest, trees and statues remain objects of worship and inspiration to grove visitors (Oyelowo et al., 2014). Resource extraction or encroachment by villagers is prohibited in the sacred grove. However, over the years, the land around Igbo-Olodumare sacred grove has been converted into an agricultural settlement, and the majority of the inhabitants are seasonal migrants in cocoa and oil palm plantations (first author's observation). The single grove staff admits tourists into the grove and must guide the tourist along the accessible sections of the grove during the tour.

\subsection{Questionnaire development}

We assessed over 20 peer-reviewed articles on sacred groves and biodiversity conservation in Nigeria, Africa and globally. We identified the various benefits provided by sacred groves to local peoples and selected the most commonly cited benefits (16 benefits) in relation to biodiversity conservation. We then grouped these 16 identified benefits into two categories (8 per category): socio-economic and religio-cultural (Table 1). We asked the respondents the level of their agreement to how these 16 benefits drive biodiversity conservation in the sacred grove using a 4-point Likert scale ranging from "strongly disagree (1)" to "strongly agree (4)". An "I don't know" option was included.

Table 1. List of possible benefits driving biodiversity conservation in sacred groves.

\begin{tabular}{ccc}
\hline Categories. & List of drivers & Sources \\
\hline Socio-economic drivers & $\begin{array}{c}\text { Income generation, provision of social amenities, } \\
\text { timber for poles and buildings, NTFPs collection, } \\
\text { fishing, hunting, tourism potential, employment } \\
\text { opportunities }\end{array}$ & $\begin{array}{c}\text { Ormsby, 2012b; Osegale et al., 2014; } \\
\text { Oyelowo et al., 2014; Probst, 2013, 2016; } \\
\text { Udeagha et al., 2013. }\end{array}$ \\
\hline Religio-cultural drivers & $\begin{array}{c}\text { Place of worship, ritual site, meeting point for } \\
\text { traditional ceremonies, ordination of kings, place to } \\
\text { seek supernatural interventions, cultural promotion, } \\
\text { shelter for deities }\end{array}$ & $\begin{array}{c}\text { Bhagwat and Rutte, 2006; Daniel et al., } \\
\text { 2016; Liljeblad and Verschuuren, 2019; } \\
\text { Probst, 2013; Yusuf, 2016. }\end{array}$ \\
\hline
\end{tabular}

\subsection{Data collection}

We used a mixed-methods approach, combining semi-structured survey questionnaires, interviews, focus group discussions and document analyses. The integration of quantitative and qualitative research methodologies capitalized on the strengths of both and compensated for their weaknesses (Bryman, 2012). Field data were collected in February and March 2019. We surveyed eight proximate communities to get a representative sample: about 65 per sacred grove, with a total of 167 people (Table 2). Our respondent group consisted of sacred grove priests, deity worshippers, artisans, farmers, traders, and students (Table 3).

Table 2. Number and category of participants who took part in the study.

\begin{tabular}{cccc}
\hline & Osun Osogbo Sacred Grove & Idanre Hills & Igbo-Olodumare \\
\hline State & Osun State & Ondo State & Ondo State \\
\hline
\end{tabular}




\begin{tabular}{cccc}
\hline Status & UNESCO World Heritage Site & Nigerian National Monument & State/Local cultural heritage site \\
\hline \# of survey respondents & $\begin{array}{c}64 \text { (6 priests; } 58 \text { community } \\
\text { members })\end{array}$ & $\begin{array}{c}63 \text { (2 priests; } 61 \text { community } \\
\text { members) }\end{array}$ & $\begin{array}{c}40^{1} \text { (1 priest; } 39 \text { community } \\
\text { members) }\end{array}$ \\
\hline $\begin{array}{c}\text { \# of focus groups } \\
\text { informants }\end{array}$ & 2 & 3 & 2 \\
\hline \# of interviews with key & 1 & Nil & 1 \\
\hline
\end{tabular}

Table 3. Overview of survey respondents' demographics across the three sacred groves.

\begin{tabular}{|c|c|c|}
\hline Variable & Total number & Percentage $(\%)$ \\
\hline \multicolumn{3}{|c|}{ Gender } \\
\hline Female & 63 & 38 \\
\hline Male & 104 & 62 \\
\hline \multicolumn{3}{|c|}{ Age range (years) } \\
\hline $18-35$ & 30 & 18 \\
\hline $36-60$ & 75 & 45 \\
\hline$\geq 61$ & 62 & 37 \\
\hline \multicolumn{3}{|l|}{ Education Level } \\
\hline Informal education & 51 & 31 \\
\hline Primary & 29 & 17 \\
\hline Secondary & 65 & 39 \\
\hline Tertiary & 22 & 13 \\
\hline \multicolumn{3}{|l|}{ Occupation } \\
\hline Agric. Rel. Jobs & 56 & 33 \\
\hline Government workers & 6 & 4 \\
\hline Others & 95 & 57 \\
\hline Unemployed & 10 & 6 \\
\hline \multicolumn{3}{|l|}{ Monthly Income (Naira - \#) ${ }^{2}$} \\
\hline $10,000-40,000$ & 77 & 46 \\
\hline $41,000-70,000$ & 45 & 27 \\
\hline $71,000-100,000$ & 5 & 3 \\
\hline$\geq 100,000$ & 16 & 10 \\
\hline Prefer not to answer & 24 & 14 \\
\hline \multicolumn{3}{|l|}{ Religion } \\
\hline Christianity & 76 & 46 \\
\hline Islam & 48 & 28 \\
\hline Traditional & 43 & 26 \\
\hline \multicolumn{3}{|l|}{ Nativity } \\
\hline Indigene & 121 & 72 \\
\hline Migrant $^{3}$ & 46 & 28 \\
\hline
\end{tabular}

We used both random and purposive sampling methods to select questionnaire respondents to ensure that we captured the views of a representative sample of community members. Some respondents filled the questionnaire themselves; others dictated their answers to the research team. The questionnaires were in English but the research team were able to translate the questionnaires in Yoruba. We were also granted two one-hour

\footnotetext{
${ }^{1}$ In Igbo-Olodumare, we could only find 40 respondents (instead of 65) to participate in this study due to the small number of community members.

2 US Dollar conversion to Nigerian Naira: 1 USD $=412.50$ Nigerian Naira in May, 2021.

${ }^{3}$ In this paper, migrants are those who migrated to the community in their lifetime while natives are those who were born and raised in and have ancestral connections to the community.
} 
semi-structured interviews, with the Head of Education Unit of OOSG and the officer in charge of Igbo-Olodumare grove. We also conducted seven hour-long focus groups across the groves in which we explored unanticipated issues that had come up during the various discussions (Marshall and Rossman, 2016). Each focus group involved four to nine participants (male and female). This study received the full approval of UBC's Behavioural Research Ethics Board and the consent of local authorities in the communities. Every participant provided consent, either verbally or in written form.

\subsection{Data Analysis}

We carried out statistical data analysis using R Studio (version 3.6.0). We used descriptive statistics (e.g., means and proportions) to summarize our results. Data from Likert scales, for which we combined the score of each Likert item into a composite scale, were assumed to be interval in nature and thus analyzed using parametric statistics. In contrast, data from individual Likert items if used individually (i.e., no attempt to combine individual responses into composite scales) were assumed to be ordinal and analyzed using non-parametric statistics (Clason and Dormody, 1994; Peterson StLaurent et al., 2018). We carried out one-way analysis of variance (ANOVA) with post hoc test Tukey Honest Significant Differences (HSD) to compare the level of agreement to the categories of benefits (i.e., the aggregated score of the eight Likert items for socio-economic and religio-cultural) driving biodiversity conservation within and between the sacred groves. We transcribed and manually coded the qualitative data from key informant interviews and focus groups. We included quoted texts from both focus groups and interviews to support the quantitative data.

\section{RESULTS AND DISCUSSION}

The analysis shows significant differences in the benefit categories (socio-economic and religio-cultural) driving biodiversity conservation among the three sacred groves. Respondents showed varying levels of agreement with the benefits under each of the two categories which suggest inter-grove differences. The one-way ANOVA indicate significant differences between the aggregated scores of the two categories of benefits in each grove. In general, respondents had greater levels of agreement that religio-cultural benefits are important drivers of biodiversity conservation compared to socio-economic benefits.

\subsection{Economic gains increase local people's commitment to sacred groves' preservation}

Our findings show strong linkages among tourism, income generation and employment across the three groves (Figure 2). 


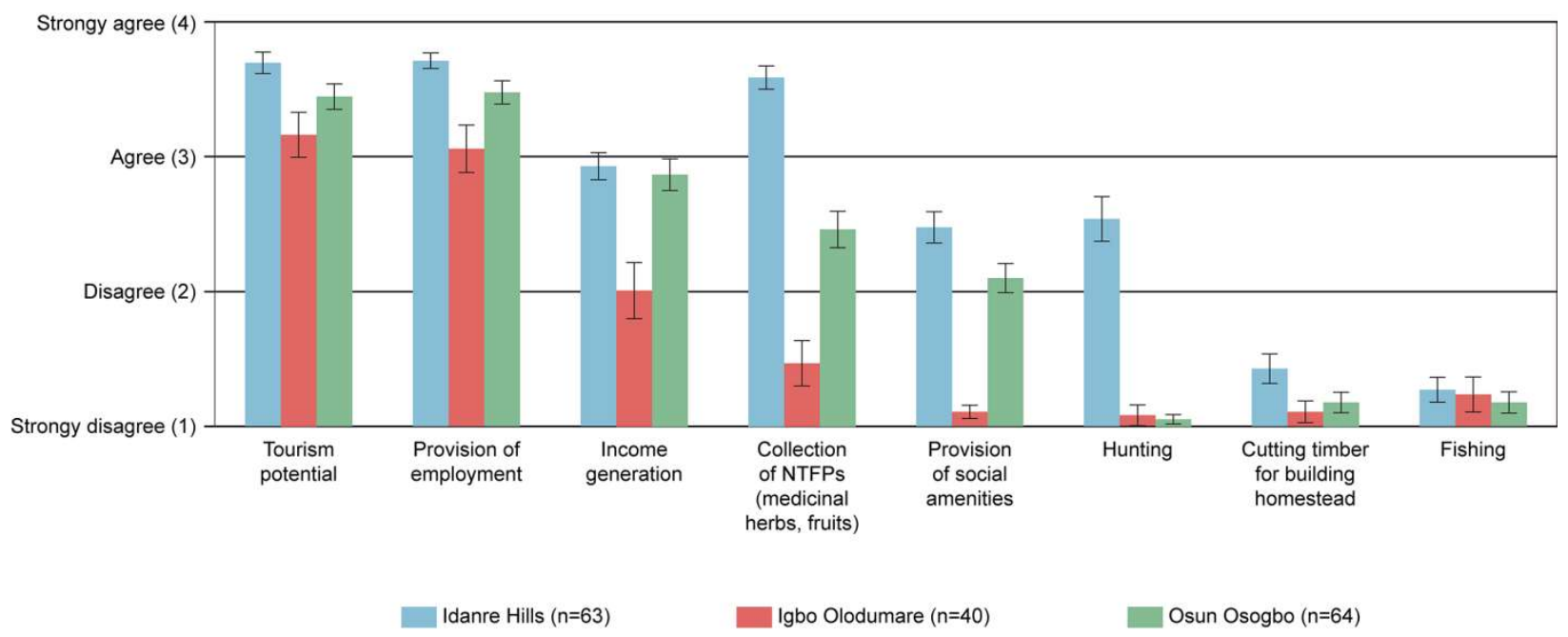

Figure 2. Mean scores and standard errors showing respondents' levels of agreement with the question "what are the socio-economic benefits that drive biodiversity conservation" in the three sacred groves using a 4-point scale from strongly disagree (1) to strongly agree (4).

Community members gain direct economic benefits from tourism and regular visits to the groves by local and international tourists, although the scale differs for each grove (Adigun et al., 2016; Onyekwelu and Olusola, 2014; Ormsby, 2012b). Local businesses ranging from hotels, eateries, tour guides, transport companies and other service providers earn considerable income, as do external businesses that operate temporarily during the festivals (Probst, 2013). One focus group participant (OOSG) explained "During the festival of Osun or even on ordinary days, people selling ritual materials such as kegs used to fetch water from Osun River, the food vendors and drink sellers benefit a lot. The commercial motorcyclist and taxi drivers benefit. Hoteliers and house rentals also benefit. These are all the ways people benefit financially through Osun Osogbo sacred grove. Also, traditionalists use the herbs from the grove for healing and that has become a source of livelihood for them."

Both Idanre Hills and OOSG have become major tourist destinations. OOSG's Osun festival attracts several thousand visitors, tourists and pilgrims, annually. This international festival has become a multi-million dollars event with sponsorship from the government and private companies especially leading telecommunication and brewery companies (Onyekwelu and Olusola, 2014; Ogundiran, 2014; Probst, 2013). An estimated 121,000 people participated in the Osun Festival in 2017. Attendance at the festival almost doubled between 2013 and 2018 based on the data obtained from NCMM Osun Osogbo Visitor Statistics (Appendix A). Reports indicate, however, that no funds from the corporate sponsorship were allocated for grove maintenance (Ogundiran, 2014). In Idanre Hills, the annual patronage of tourists in the Orosun festival ranged from 600 to 8,700 people between 2005 and 2013 (Adigun et al., 2016). The State government has promoted ecotourism in Idanre Hills grove by organizing an international mountain climbing, musical and cultural festival called "Mare festival" since 2009 (Adigun et al., 2016). The annual festival both contributes to creating awareness and increasing visitors to the grove while promoting the culture and tradition of Idanre people (Adigun et al., 2016).

In the case of Igbo Olodunmare, the third grove we assessed, the majority of visitors are students from tertiary institutions who visit for sightseeing, education, and research purposes: "When tourists visit, usually 
students on excursion to the site, villagers sell their farm produce to them. Although this is not regular, the few visits make much difference. Since everyone in the village is a farmer, you cannot sell your farm produce to other villagers. You have to transport the produce to markets outside the village to sell. But with buyers at your doorstep, you save your transport fare and sell at a good price to the tourists." (Key informant interview, Igbo Olodumare SG). This and other comments suggest that despite the absence of large-scale tourism activities in Igbo-Olodumare, the tourist visits still contribute to the rural economy.

The government earns revenue from the collection of access fees to the groves. All visitors except for Osun devotees pay an entrance fee in OOSG. That income is shared between the NCMM and the Osogbo Cultural Heritage Council (OCHC), headed by the king of Osogbo (NCMM, 2014). In addition, a portion of the revenue is used for conservation purposes. In Idanre Hills, the entrance fees contribute to the Internally Generated Revenue (IGR) of the state, workers' salaries and maintenance of the site (Oladeji and Akinrinola, 2010). A focus group participant (Idanre Hills) opined that "the Hills is a tourist center that generates funds and serves as a revenue source through the community to the government. The community and the local government get their share."

At Idanre, the Usé festival (annual bat hunting festival) provides income for young men who capture bats that are used in cultural rituals, eaten or sold as bushmeat (Bai et al., 2018). For the Yoruba people, bats are divine messengers (Adebayo, 2017). A focus group participant (Idanre Hills) observed that "Usé festival is one of the rituals in Idanre, which is the killing of bats on the Hills once a year. The bats are sold or eaten by households. One of the bats is also used for prayers for the peace and protection of the community - safe delivery of pregnant women and youths' protection". The bats are protected through local customs which forbid entry into the caves except during the biannual bat festival, thereby ensuring a sustainable bat population. On all other occasions, permission must first be sought from the community leadership before the caves can be visited (Bai et al., 2018). There is no evidence that the bat population has dwindled due to the ancient practice of bat hunting during the Usé festival. We conclude that the strictly controlled harvesting of bats, and the restriction of bat harvesting to two festival seasons per year helps the bat population to remain healthy. Scientists have expressed concerned about the potential risk of transmission of bat-borne pathogens to humans due to the presence of fruit bats and bat flies which harbor Bartonella strains (Bartonella rousetti), a bacterial disease capable of infecting humans and close human-to-bat contact prevalent during the Usé festival (Bai et al., 2018). In light of the current COVID-19 zoonotic disease, with a record 180 million cases and over 4 million deaths reported as of 29 June, 2020, relevant health agencies may pay more attention to festivals like the Usé, to map potential inter-species virus transmission (Dobson et al., 2020; Johns Hopkins University (JHU), 2021).

Across the three groves, there was scant evidence of any communitylevel project funded from tourism revenues. In fact, respondents held contrasting views on whether revenues are generated, who receives them, and what percentage, if any, is utilized for community development. One focus group participant (Idanre Hills) opined: "If any revenue is generated from the Hills, it should be used to develop the place. The money collected, we do not know where they put the money at all, even the road leading to the grove is already bushy." This was a widely shared sentiment and illustrates the absence of communication between the sacred grove managers (usually government 
staff) and community residents. Even though revenue from sacred grove operations may have been used for community projects, the lack of downward accountability may create doubt and suspicion among community members.

The benefits resulting from the prestige and popularity brought to the study communities by the three groves and associated festivals (Probst, 2013) serve as a rationale for local conservation efforts. This finding is consistent with studies in Ghana, India (Ormsby, 2012b) and Nigeria (Onyekwelu and Olusola, 2014), suggesting that economic incentives created by employment, tourism and revenue generation encourage the commitment of local communities to protect and preserve sacred groves. At the same time, if not adequately managed, mass tourism could pose a threat to sacred groves because of the negative consequences of increased pressure including solid waste disposal issues, ecological impacts and loss of cultural integrity (Ormsby, 2012b). The two most pressing challenges facing tourism in OOSG were identified as insufficient public utilities/public toilets and carrying capacity issues (Yusuf, 2016). Due to the large influx of visitors during the festival, the traditional cult in OOSG raised concerns about the loss of control over access to sacred sites and structures at the grove, thereby making it difficult to maintain the secrecy and privacy associated with communication with and worship of the Osun goddess (Probst, 2013).

On balance, our findings support those of Samakov and Berkes, (2017) which found that increased visitation to a site positively impacts conservation efforts. In the case of the three sacred groves, the huge traffic created by both traditional worshippers and tourists' patronage has contributed to conservation of the groves. If not, these groves would have been abandoned or vanished, as have many other sacred groves in Yoruba territory (NCMM, 2005).

\subsection{Religio-cultural benefits are the core driver of biodiversity conservation in sacred groves}

The respondents across the three sacred groves strongly agreed that religio-cultural benefits are essential drivers of biodiversity conservation. The three sites share similarities in the religio-cultural benefits such as usage for traditional and community festivals, sites of worship and kingmaking rituals (Figure 3).

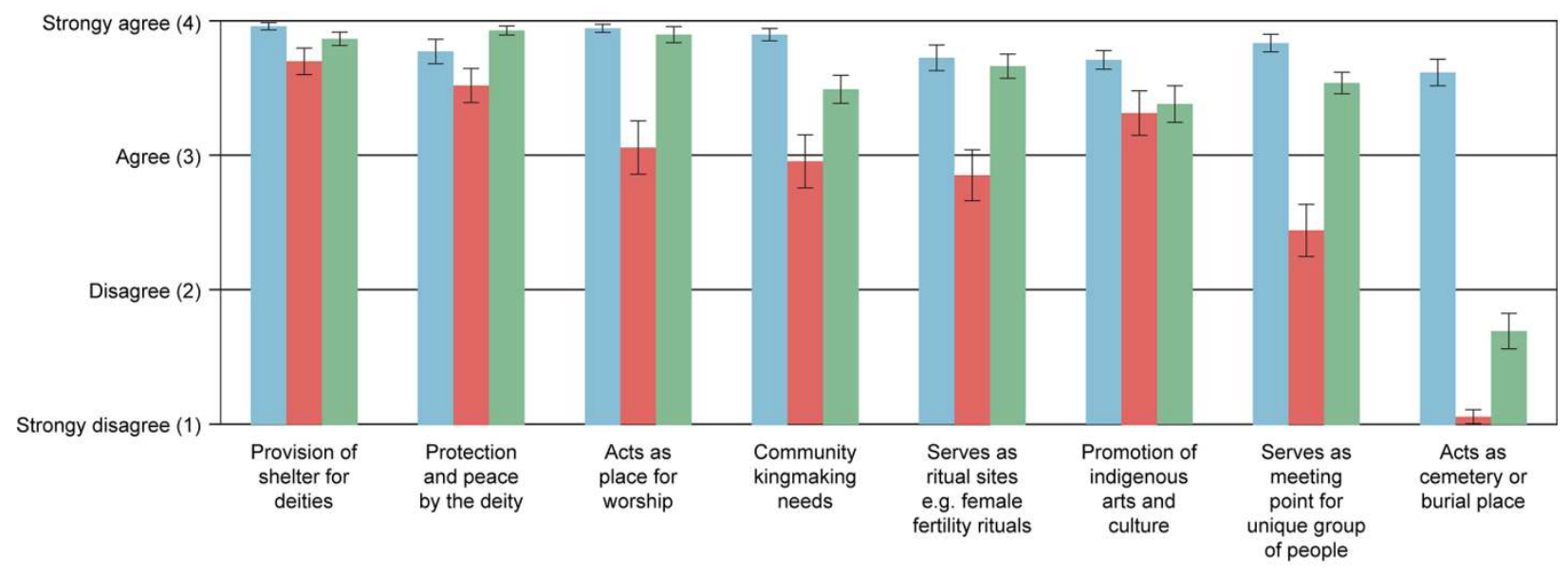


Figure 3. Mean scores and standard errors showing respondents' levels of agreement with the question "what are the religio-cultural benefits that drive biodiversity conservation" in the three sacred groves, using a 4-point scale from strongly disagree (1) to strongly agree (4).

At the heart of traditional practices and norms are individual and communal worship of gods and celebration of traditional festivals (Adebayo, 2016; Onyekwelu, 2021; Onyekwelu and Olusola, 2014; Probst, 2013). Significantly, the establishment of both Osogbo and Idanre towns can be traced back to the groves ${ }^{4}$. In the case of OOSG, the annual sacrifices made in the grove serve both to commemorate the pact and renew the relationship between Osun goddess and the first king of Osogbo and by extension the entire Osogbo people (Ogundiran, 2014; Probst 2016). This ancestral relationship between Osogbo kings (Ataoja) and the grove is further proven by the location of the first and second palaces inside OOSG and the special interest and involvement of the king in the 12-day Osun Osogbo festival which also takes place in the grove (NCMM, 2005). A focus group participant (OOSG) hinted: "Osun Osogbo grove is our place of origin (ancestral home), which must not be destroyed. It houses the worship points, and the spirit of the goddess lives in the grove. The flamboyant 12-day Osun Osogbo festival ${ }^{5}$ and associated pilgrimage to OOSG underscore the central role of the grove in shaping the identities of Osogbo people, further reinforcing its significance and the rationale for its preservation.

At Idanre Hills, worshippers offer prayers mainly during the traditional festivals and some local chiefs perform indoor ritual sessions on the Hills for a few days. Similarly, Osogbo people esteem Osun as not just a river but as the guardian deity who provides beauty, wealth and fertility for her worshippers (Probst, 2013; Yusuf 2016). A focus group participant (OOSG) noted: "Some people have received different kinds of benefits from the Osun goddess that must come back to the grove to pay back their vows annually during Osun Osogbo festival. Some people who have faced one difficulty or the other in their jobs or businesses or are experiencing barrenness have the opportunity to consult the traditionalists on-site." Similar reasons were reported as the purpose of visiting sacred sites in Kazakhstan by Samakov and Berkes (2017).

In both OOSG and Idanre Hills, the king and chief priests officiate at special rituals at midnight in specific parts of each grove. One participant (Idanre Hills) emphasized this: "Even though we have moved downhill, we did not forget the Hills. We still reference the Hills in everything we do, such as the installation of our king, and most of the traditional rites are done on the Hills." Other studies on sacred groves in the south and southeast regions of Nigeria confirmed the use of sacred groves as meeting places for community kingmakers in charge of selection and installation of legitimate kings, coronation ceremonies of traditional leaders and for masquerade ceremonies (Daniel et al., 2016; Udeagha et al., 2013). Similarly, traditional groups hold their meetings in areas in the sacred groves where tourists are forbidden to enter (Osegale et al., 2014). An example is the Ogboni cult that meets in OOSG every 15 days ( 3 traditional weeks) and daily during the Osun Osogbo festival (Osegale et al., 2014). Probst recounted an instance when the king (Ataoja) of Osogbo discounted the religious relevance of the grove and festival as just mere sites of commemoration and remembrance (2013). The

\footnotetext{
${ }^{4}$ For OOSG, see (NCMM, 2005, p. 13 -14 and Probst 2016, p.253) for variants of the oral traditional history. For Idanre Hills, see (NCMM, 2007)

${ }^{5}$ See (NCMM, 2005, pp.53 - 56) for details of the daily activities during the 12-day festival.
} 
Osun priests and religious cults protested the king's view and re-emphasized the traditional religious importance of the grove and festival (Probst, 2013), underlining the grassroots support. The Yoruba people of southwest Nigeria utilize the leaves of the Akoko tree (Newbouldia laevis) for the coronation of traditional rulers and conferment of chieftaincy titles (Babalola, 2011). Such trees, among others, are highly protected for their important usage, thus validating the contributory role played by sacred groves in conserving biodiversity (Babalola, 2011).

In Igbo-Olodumare grove, some religio-cultural indicators, including the provision of shelter for deities and protection and peace of the deity, had high ratings (Figure 3). However, the influx of immigrant farmers/traders, absence of elders with traditional knowledge, and decline in traditional festival observances threaten the continued preservation of Igbo-Olodumare. A historical myth that is still popular among community members forbids unauthorized access to the grove, although the actual traditional worship of deities is almost nonexistent. In fact, respondents revealed that the only traditional festival celebrated in the village had not taken place in the past two decades. This confirms the findings by Onyekwelu and Olusola (2014) that only half of the community perceived the Igbo-Olodumare grove to be a historical and cultural site while less than 25 per cent considered the grove as the home of the deity and place of worship, hence the low sacredness status assigned to the grove. A contributing factor is that local elders who should lead the traditional festivals have migrated to bigger communities to live with their adult children. The high number of abandoned mud houses that we counted in Igbo-Olodumare provided evidence of the high rate of migration. Since local elders play important roles in upholding ancient local norms and traditions, the increasing diminution in their numbers in IgboOlodumare may lead to further deterioration of the sacred nature of the grove and consequent loss of its biodiversity. Looking across to Benin Republic, local leaders properly enforced traditional taboos and prohibitions in riparian communities to prevent migrants and locals from disregarding the traditional beliefs necessary for preserving sacred forests (Ceperley et al., 2010). Studies have shown that an influx of migrants with scant knowledge of the traditional norms of an area may hamper the biodiversity conservation in sacred groves (Nganso et al., 2012). Igbo-Olodumare is a hub for immigrant farmers. The grove is now surrounded by farms, which if left unchecked, may encroach into the grove in the coming years. There is an urgent need for raising awareness of traditional values among immigrants combined with strict enforcement of governmental preservation laws to avoid potential encroachment in the future.

In the two other groves, we found widespread awareness of the traditional practices and taboos in place for protecting the groves (notion of sacredness) and an acknowledgement that trespassing could attract serious punishment for both the trespasser and the entire community (Rutte, 2011; Samakov and Berkes, 2017). These findings align with a study in the Bongo District of Ghana (Aniah and Yelfaanibe, 2016), where violations of the traditional rules protecting the grove were perceived to have attracted sanctions on the whole community from the gods. As noted earlier, hunting, fishing, and cutting of trees are not allowed in Igbo-Olodumare and OOSG (Onyekwelu and Olusola, 2014; Probst, 2013). If caught, violators may be arrested and handed over to the police or required to make special sacrifices to appease the gods. The threat of a penalty acts as a deterrent. Onyekwelu (2021) concluded that the fear and respect of $\operatorname{god}(\mathrm{s})$, fear of negative 
consequences for actions that harm sacred groves or violate the rules/taboos and the belief that the god(s) protect inhabitants, all serve as motivations for protecting sacred groves, and consequently, conserving biodiversity. We note however, in Idanre Hills, firewood and other NTFPs collection and hunting are not strictly prohibited because the entire village was formerly sited on the Hills and villagers had customary use rights. Some villagers still gather firewood and other NTFPs and farm on the non-sacred parts of the Hills.

\subsection{Formal institutional management influences biodiversity conservation across the sacred groves}

Our results indicate that the formal institutional ${ }^{6}$ management of sacred groves positively impacts the level of protection. Collaborative management of sacred spaces between government institutions and local communities has proven effective in protecting and preserving them (Nganso et al., 2012) in places where traditional norms and practices are disappearing or seen as oldfashioned due to the adoption of western values and modern religions (Aniah and Yelfaanibe, 2016; Khan et al., 2008; Rutte, 2011; Sheridan, 2009). Records show that OOSG was almost degraded and deserted in the 1950s, partly due to the rising intolerance of the Yoruba religion among the Muslims in the community, resulting in massive encroachment into the grove by farmers and timber companies (Probst, 2009). The traditional beliefs and taboos were in danger of disappearing (Onyekwelu, 2021; Onyekwelu and Olusola, 2014). The revival of traditional cultural practices and subsequent government and UNESCO designation of the grove ${ }^{7}$ are credited to Susanne Wenger, an Austrian artist who moved to Nigeria with her husband in the 1950s (Probst, 2009). Wenger received the blessing of the then king (Ataoja) Adenle, who pushed for the declaration of the grove as a national monument (Probst, 2009). She was later appointed the chief priestess of the Osun goddess and given the Yoruba name, Adunni Olorisa. Her contribution was recognized in one of UNESCO's inscription criteria for designating OOSG as a World Heritage Site which states "the development of the Movement of New Sacred Artists and the absorption of Susanne Wenger, an Austrian artist, into the Yoruba community have proved to be a productive exchange of ideas that revived Osun Osogbo sacred grove" (NCMM, 2005).

The degree of institutionalization of $\mathrm{OOSG}^{8}$ is not only evident in its designations - Nigerian national monument in 1965, the national museum in the 1990s and UNESCO World Heritage Site in 2005 (Probst, 2013, 2016; Yusuf, 2016) - but also in the level of finances, human resources, laws and decrees committed to protecting the site. The Nigerian Federal government's financial commitment to the grove and festival increased after its designation as a UNESCO site (Probst, 2013). The annual salary for 115 staff in 2011 is estimated at several million Nigerian Naira (NCMM, 2014). The number of

\footnotetext{
${ }^{6}$ We define "formal institution" as the rules that guide access, control and management of multi-user resources, and which are backed up and enforced by the state (Yami et al., 2009)

7 See Ogundiran, (2014) for criticism of the nomination process for the grove. The process was largely bureaucratic and lacked substantial participation of the host community. For instance, the NCMM senior staff prepared the 90-page nomination document and delegation to the World Heritage Committee meeting in Durban (where OOSG was designated as World Heritage Site) were comprised mostly of the federal (Nigeria) and state (Osun) governments officials.

8 There are three layers of institutional authority for the grove according to Ogundiran, (2014). Hereby arranged according to hierarchy: (1) The federal government, through NCMM is responsible for the overall management of the grove, (2) The Osun State government and the Osogbo and Olorunda local governments (3) The Osogbo community governed traditionally through the king (Ataoja) of Osogbo and Osun chief priestess.
} 
staff reportedly far more than is needed in the grove, creating idleness (Ogundiran, 2014). However, the rules and regulations help to strengthen the protection of OOSG. The NCMM also provided funding for fencing of the buffer zone, in addition to the armed patrols. However, Ogundiran, (2014) argued that government spending has not contributed to the sustainable maintenance and preservation of OOSG due to the neglect of physical structures within it which are overgrown by weeds.

We note the research which has shown that government involvement in the day-to-day management of sacred groves could negatively impact local communities' involvement and sense of ownership (Probst, 2013), thus alienating the host communities (Akinde, 2018; Aniah and Yelfaanibe, 2016). For example, the official recognition of Igbo-Olodumare by the Ondo state government was associated with the erection of a boundary fence. Although the fence may contribute to protecting the site from illegal access, extensive research has shown the negative impact of fencing on the free movement of wildlife and people. The resulting habitat fragmentation, reduced landscape connectivity, wildlife injuries and mortality, and alienation of local people from their cultural heritage are a few consequences of fencing (Ferguson and Hanks, 2010, Jakes et al., 2018). At the same time, those authors noted the important role of fencing in preventing human-wildlife conflict and wildlifelivestock disease transmission across many landscapes. Tensions over management rights occasionally occur between traditional leaders and State agencies. For example, in OOSG, there was conflict between the king (Ataoja) of Osogbo and the NCMM regarding registration of visitors to the grove. It took the intervention of the International Council of Monuments and Sites (ICOMOS) to resolve the issue (Akinde, 2018).

Due to the perception that government involvement may strip local people of sacred grove ownership, other communities in southern Nigeria rejected government-imposed laws and regulations aimed at protecting their sacred sites (Daniel et al., 2016). The enduring memory of unilateral reservations of forest estates at the state and federal government levels in Nigeria has created mistrust between local communities and government agencies (Daniel et al., 2016). In contrast, a study in northern Ghana found that community members approached the government to institute a law to prohibit locals from continued encroachment and degradation of their sacred grove (Nganso et al., 2012). Despite the often complex and challenging relationship between authorities of formal institutions (e.g. NCMM) and host communities, the distinct and complementary roles played by both management institutions have been critical to conservation of the groves. As Ogundiran (2014) puts it "the challenge remains balancing the good intentions of the state with the needs of the local community in historical, community identity, and spiritual terms" (p. 177).

Looking ahead, Nigeria is a signatory to numerous international convention and agreements, with different targets set for biodiversity conservation, and combating climate change (Federal Ministry of Environment (FME), 2015a; FME, 2015b; Oluduro and Gasu, 2012). Nigeria also committed to sustainably manage at least 10 per cent of its national territory as conservation areas by 2020 (FME, 2015a). Sacred groves in Nigeria can be made more visible by being folded into the national policy framework for achieving long-term national biodiversity targets, as in some other parts of the world (Tibetan region, western China and British Columbia province, Canada) (Samakov and Berkes, 2017). Such recognition would both demonstrate Nigeria's commitment to conserving its dwindling natural 
resources and affirm the relational values that link the Yoruba and other peoples to their sacred groves.

\section{CONCLUSIONS AND RECOMMENDATIONS}

Our research has highlighted that religio-cultural associations with the groves serve as critical motivations for their protection, albeit to varying extents. As long as the groves continue to be central in shaping the identities of the Yoruba People, the site of traditional festivals and occult meetings and symbols of spiritual powers, they, and the biodiversity therein, will be preserved. We also found that economic incentives from tourism, employment opportunities and income generation activities contribute to successful biodiversity conservation in these sacred groves. Residents of OOSG and Idanre hills benefit from big festivals associated with the grove while in Igbo-Olodumare local people valued the opportunistic economic benefits derived from the occasional visits from students and tourists. However, it was unclear to the community members interviewed in all three groves how revenue from the grove was managed or utilized by the respective administrators.

We found that formal institutional management is positively correlated with protection of the groves. The dwindling adherence to traditional beliefs and practices, combined with Elders moving to urban areas and migrant workers and industrial farming increasing (Igbo-Olodumare), confirm the need for continuing involvement of government institutions in the management of sacred groves. Hence, a mix of customary and formal institutional management using cultural norms and prohibitions in the former, and state-enforced rules (constitution, laws, regulations) in the latter are critical to biodiversity conservation. Both types of institutional arrangement have complemented each other over the past decades and help to explain the resilience of sacred groves in Nigeria. Co-management of groves is increasingly becoming the norm in West Africa (Aniah and Yelfaanibe, 2016; Nganso et al., 2012). We recommend that, as far as possible, the principle of subsidiarity, where decisions are made at the lowest effective level of authority rather than by a central authority, should be followed. The informal institutions including local communities need to be recognized as rightsholders and be involved in decision-making for the improved management of the groves. We also recommend that community-based organizations could be supported to uphold and preserve their Traditional Ecological Knowledge (TEK), manifested in cultural values and festivals that have proved effective in protecting the remaining biodiversity in sacred groves.

Finally, our research indicates the need for transparency in the sharing and utilization of tourism revenues in host communities. We suggest that government officials should improve communication channels and meet regularly with community inhabitants to ensure accountability and transparency in management decisions. Communities would welcome shared decision-making with government agencies on the utilization of tourism revenues. Further, since outright fencing and padlocking of groves (e.g. Igbo-Olodumare) prohibit people with customary rights access to the grove and also limit wildlife range, government should engage relevant stakeholders, especially affected communities, to work out solutions that guarantee community access, and support the biodiversity in the sacred sites. Relatedly, we recommend that state and federal governments should buy 
back land parcels adjacent to each grove, as part of a strategy to provide linking corridors for migration of wildlife. The long-term resilience of the sacred groves depends in equal measure on governance reforms and landscape-level approaches.

\section{REFERENCES}

Adebayo, A. (2017). Sustainable tourism and cultural landscape management: the case of Idanre Hill, Ondo State, Nigeria. Tourism Today, 16(16/17), 43-55.

Adesiji, G. B., \& Babalola, F. D. (2012). Sacred forests: Indigenous knowledge and cultural beliefs for conservation of forests in Ifo Local Government Area of Ogun State, Nigeria. African Journal of Sustainable Development, 2(1), 117-134.

Adigun, F.O., Abolade, F., \& Adegboye, D.I. (2016). Patronage pattern of Idanre Hills as eco-tourism centre. Research on Humanities and Social Sciences, 6(12), 35-42.

Akinde, C.O. (2018). Participatory approach to archaeological heritage management Oke-Idanre Cultural Landscape - a case study. In Paper presented at the ICOMOS-ICAHM 2018 Annual Meeting: Discover Sicily's Argimusco - a Holistic Approach to Heritage Management 25-28 October 2018, Montalbano Elicona, Province of Messina, Sicily, Italy.

Aniah, P., \& Yelfaanibe, A. (2016). Learning from the past: The role of sacred groves and shrines in environmental management in the Bongo district of Ghana. Environmental Earth Sciences, 75(10), 916. https://doi.org/10.1007/s12665-016-5706-2

Babalola, F.D., (2011). Roles of and threats to Yoruba traditional beliefs in wilderness conservation in southwest Nigeria. Presented at the Ninth World Wilderness Congress Symposium. Meridá, Yucatán, Mexico, pp. 125-129.

Bai, Y., Osinubi, M. O., Osikowicz, L., McKee, C., Vora, N. M., Rizzo, M. R., ... \& Kosoy, M. Y. (2018). Human exposure to novel Bartonella species from contact with fruit bats. Emerging infectious diseases, 24(12), 2317. https://doi.org/10.3201/eid2412.181204

Bhagwat, S. A., \& Rutte, C. (2006). Sacred groves: potential for biodiversity management. Frontiers in Ecology and the Environment, 4(10), 519-524. https://doi.org/10.1890/15409295(2006)4[519:SGPFBM]2.0.CO;2

Brandt, J. S., Wood, E. M., Pidgeon, A. M., Han, L. X., Fang, Z., \& Radeloff, V. C. (2013). Sacred forests are keystone structures for forest bird conservation in southwest China's Himalayan Mountains. Biological Conservation, 166, 34-42. https://doi.org/10.1016/j.biocon.2013.06.014

Bryman, A., (2012). Social Research Methods (4th ed.). Oxford University Press.

Bulkan, J., 2017. Social, cultural and spiritual needs and values. In J. Innes \& A. Tikina (Eds.), Sustainable Forest Management: From Concept to Practice (pp. 241 - 256). Earthscan.

Ceperley, N., Montagnini, F., \& Natta, A. (2010). Significance of sacred sites for riparian forest conservation in Central Benin. Bois et forêts des tropiques, 64(303), 5-23.

Clason, D. L., \& Dormody, T. J. (1994). Analyzing data measured by individual Likert-type items. Journal of agricultural education, 35(4), 4.

Daniel, K. S., Udeagha, A. U., \& Jacob, D. E. (2016). Socio-cultural importance of sacred forests conservation in south southern Nigeria. African Journal of Sustainable Development, 6(2), 251-268.

Dobson, A. P., Pimm, S. L., Hannah, L., Kaufman, L., Ahumada, J. A., Ando, A. W., ... \& Vale, M. M. (2020). Ecology and economics for pandemic prevention. Science, 369(6502), 379-381. https://10.1126/science.abc3189

Dudley, N., Bhagwat, S., Higgins-Zogib, L., Lassen, B., Verschuuren, B., \& Wild, R., (2010). Conservation of biodiversity in sacred natural sites in Asia and Africa: A review of the scientific literature. In: B. Verschuuren, R. Wild, J. McNeely, G. Oviedo (Eds.), Sacred Natural Sites Conserving Nature and Culture (pp. 19-32). Earthscan.

Federal Ministry of Environment (FME), Federal Republic of Nigeria, (2015a). National Biodiversity Strategy and Action Plan 2016-2020. Available at https://www.cbd.int/doc/world/ng/ng-nbsap-v2en.pdf

FME, (2015b). Nigeria's Intended Nationally Determined Contribution (INDC). Available at 
https://www4.unfccc.int/sites/ndcstaging/PublishedDocuments/Nigeria\%20First/Approved\%20Nige ria\%27s\%20INDC 271115.pdf

Ferguson, K., Hanks, J. (Eds.). (2010). Fencing Impacts: A review of the environmental, social and economic impacts of game and veterinary fencing in Africa with particular reference to the Great Limpopo and Kavango-Zambezi Transfrontier Conservation Areas. Mammal Research Institute, Pretoria, South Africa, 329 pp.

Gabay, M., Barros, S., \& Bessonart, S., (2012). Latin America-Argentina, Bolivia and Chile. In J. A. Parrotta \& R. L. Trosper (Eds.), Traditional Forest-Related Knowledge: Sustaining Communities, Ecosystems and Biocultural Diversity. (pp. 79-117). Springer. https://doi.org/10.1007/978-94-007-2144-9 3

Garnett, S. T., Burgess, N. D., Fa, J. E., Fernández-Llamazares, Á., Molnár, Z., Robinson, C. J., ... \& Leiper, I. (2018). A spatial overview of the global importance of Indigenous lands for conservation. Nature Sustainability, 1(7), 369-374. https://doi.org/10.1038/s41893-018-0100-6

Jakes, A. F., Jones, P. F., Paige, L. C., Seidler, R. G., \& Huijser, M. P. (2018). A fence runs through it: A call for greater attention to the influence of fences on wildlife and ecosystems. Biological Conservation, 227, 310-318 https://doi.org/10.1016/j.biocon.2018.09.026

Johns Hopkins University (JHU) 2021. COVID-19 Case Tracker. https://coronavirus.jhu.edu/map.html (Accessed 29 June, 2021).

Khan, M.L., Shalata, A., Khumbongmayum, D., \& Tripathi, R.S. (2008). The sacred groves and their significance in conserving biodiversity: An overview. International Journal of Ecology and Environmental Sciences 34(3), 277-291.

Kolawole, F., n.d. Exploring the Wilds of Igbo-Olodumare. 234 Project. https://the234project.com/state-andtourism/nigeria/exploring-the-wilds-of-igbo-olodumare/ (Accessed January 10, 2020).

Liljeblad, J., \& Verschuuren, B. (Eds.). (2019). Indigenous Perspectives on Sacred Natural Sites: Culture, Governance and Conservation (1st ed.). Routledge. https://doi.org/https://doi.org/10.4324/9781351234900

Malhotra, K.C., Gokhale, Y., \& Chatterjee, S., (2001). Cultural and ecological dimensions of sacred groves in India. Indian National Science Academy.

Marshall, C., Rossman, G.B., 2016. Designing Qualitative Research (6th ed.). SAGE.

Mgumia, F., \& Oba, G. (2003). Potential role of sacred groves in biodiversity conservation in Tanzania. Environmental Conservation, 30(3), 259-265. https://doi.org/10.1017/S0376892903000250

National Commission for Museums and Monuments (NCMM), (2005). Nomination to the World Heritage List of Osun-Osogbo Sacred Grove, Osogbo, Osun State, Nigeria. Available at https://whc.unesco.org/uploads/nominations/1118.pdf

NCMM, (2007). Nomination to the World Heritage List of Oke Idanre (Idanre Hill), Ondo State, Nigeria. https://whc.unesco.org/en/tentativelists/5169/ (Accessed January 10, 2020).

NCMM, (2014). Osun Osogbo Sacred Grove. UNESCO World Heritage Site. Conservation Management Plan 2015- 2019.

Nganso, T.B., Kyerematen, R., \& Obeng-Ofori, D. (2012). Review of biodiversity in sacred groves in Ghana and implications on conservation. Current Trends in Ecology. 3, 1-10.

Ogundiran, A. (2014). The Osun-Osogbo grove as a social common and an uncommon ground: An analysis of patrimonial patronage in postcolonial Nigeria. International Journal of Cultural Property. 21(2), 173198. https://doi.org/10.1017/S0940739114000058

Oladeji, S.O., \& Akinrinola, O.O. (2010). Potentials of cultural heritage tourism as basis for sustainable heritage site development in Nigeria. Applied. Tropical Agriculture. 15(1), 6-11.

Oluduro, O.F., \& Gasu, G.N. (2012). A critical appraisal of the legal regime for biodiversity conservation in Nigeria. Canadian Social Science. 8(4), 249-257. http://dx.doi.org/10.3968/j.css.1923669720120804.3020

Onyekwelu, J.C. (2021). Can the fear of the gods sustain biodiversity conservation in sacred groves? Academia Letters. 635, 1-11. https://doi.org/10.20935/AL635

Oyekwelu, J.C., \& Olusola, J.A. (2014). Role of sacred grove in in-situ biodiversity conservation in rainforest zone of south-western Nigeria. Journal of Tropical Forest Science, 26(1), 5-15.

Ormsby, A., (2012a). Cultural and conservation values of sacred forests in Ghana. In: G. Pungetti, G. Oviedo \& D. Hooke, (Eds.), Sacred Species and Sites: Advances in Biocultural Conservation (pp. 335 -350). Cambridge University Press.

Ormsby, A. (2012b). Perceptions of Tourism at Sacred Groves in Ghana and India. Recreation and Society in Africa, Asia and Latin America, 3(1), 1-18 
Ormsby, A., \& Bhagwat, S. (2010). Sacred forests of India: A strong tradition of community-based natural resource management. Environmental 320-326. https://doi.org/10.1017/S0376892910000561

Osegale, G.E., Omisore, E.O., \& Gbadegesin, J.T. (2014). Exploratory survey on the maintenance of OsunOsogbo sacred grove, Nigeria. African Journal of Hospitality, Tourism and Leisure, 3(2), 1-22.

Oyeleke, O.O., Ogunjemite, B.G., \& Ndasule, N.A. (2017). Assessment of collaborative and multi-level management of Osun Osogbo Sacred Grove, Nigeria: A world heritage site. International Journal of Development and Sustainability, 6(7), 439-450.

Peterson St-Laurent, G., Hagerman, S., Kozak, R., Hoberg, G. (2018). Public perceptions about climate change mitigation in British Columbia's forest sector. PLoS ONE, 13(4), 1-25. https://doi.org/10.1371/journal.pone.0195999

Probst, P. (2009). Modernism Against Modernity: A Tribute to Susanne Wenger. Critical Intervention, 2(3/4), 245-255. https://doi.org/10.1080/19301944.2008.10781356

Probst, P. (2013). Preserving heritage and the values of exchange: Lessons from Nigeria. History Compass. 11(2), 1035-1046. https://doi.org/10.1111/hic3.12102

Probst, P., (2016). Prickly prestations: Living with (World)Heritage in Nigeria. In: C. Brumann \& D. Berliner, (Eds.), World Heritage on the Ground: Ethnographic Perspectives (pp. 248-272). Berghahn Books.

Rutte, C. (2011). The sacred commons: Conflicts and solutions of resource management in sacred natural sites. Biological Conservation, 144, 2387-2394. https://doi.org/10.1016/j.biocon.2011.06.017

Samakov, A., \& Berkes, F., (2017). Spiritual commons: sacred sites as core of community-conserved areas in Kyrgyzstan. International Journal of the Commons, 11(1), 422-444. https://doi.org/10.18352/IJC.713

Sheridan, M.J. (2009). The environmental and social history of African sacred groves: A Tanzanian case study. African Studies Review, 52(1), 73-98. https://doi.org/10.1353/arw.0.0149

Sobrevila, C., (2008). The Role of Indigenous Peoples in Biodiversity Conservation: The Natural but Often Forgotten Partners. The World Bank.

Udeagha, U.A., Udofia, I.S., \& Jacob, D.E. (2013). Cultural and socio-economic perspectives of the conservation of Asanting Ibiono Sacred Forests in Akwa Ibom State, Nigeria. International Journal of Biodiversity and Conservation, 5(11), 696-703. https://doi.org/10.5897/IJBC2013.0580

Verschuuren, B., Wild, R., McNeely, J.A., \& Oviedo, G. (Eds.), (2010). Sacred natural sites conserving nature and culture (1st ed.). Earthscan

Yami, M., Vogl, C., \& Hausera, M. (2009). Comparing the effectiveness of informal and formal institutions in sustainable common pool resources management in Sub-Saharan Africa. Conservation and Society, 7(3), 153-164. https://doi.org/10.4103/0972-4923.64731

Yusuf, T.G. (2016). A micro analysis of tourists, other participants and tourism activities at Osun Osogbo Sacred Grove, Nigeria. Journal of Economics and Sustainable Development. 7(7), 96-104. 